centration found in the left atrium. ${ }^{7}$ Were reinnervation to spread from preexisting ganglia within the donor heart, one would anticipate that nerve proliferation would emanate from the right atrium and other small sites where ganglia are concentrated.

The notion that chest pain during myocardial ischemia could originate from the atrial remnant or other chest organs is difficult to accept. If the pain came from the recipient's tissue, then the occurrence of pain should have had no relation to markers of donor reinneration and no correlation with ischemic cardiac events (the opposite of our observations).

We appreciate the comments of Dr. Uretsky. His experience reinforces the importance of sensory reinnervation after cardiac transplantation.

ROBERT F. WILSON, M.D. ANDreW L. MCGINN, M.D. Randall P. Stark, M.D.

Minneapolis, MN 55455

University of Minnesota

1. Elthson JP. Hibbs RG. An ultrastructural study of mammalıan cardiac ganglia. J Mol Cell Cardiol $1976 ; 8: 89-101$

2. Stoter WA. McMahon RA. The innervation and structure of the conductive system of the human heart. J Comp Neurol 1947:87:57-83.

3. Gu J. Polak JM, Allen JM, et al. High concentrations of a novel peptide, neuropeptude $Y$, in the innervation of mouse and rat heart. J Histochem Cytochem 1984;32:467-72.

4. Cooper $T$, Willman $\mathrm{VL}$. Jellınek $M$, Hanton $\mathrm{CR}$. Heart autotransplantation: effect on myocardial catecholamine and histamine. Science 1962:138:40-1.

5. Wilson RF, Christensen BV, Olivari MT, Simon A, White CW, Laxson DD. Evidence for structural sympathetic reinnervation after orthotopic cardiac transplantation in humans. Circulation 1991:83:1210-20.

6. Schwarger M, Kalff $V$, Rosenspire $K$, et al. Noninvasive evaluation of sympatheuc nervous system in human heart by positron emission tomography. Circulation 1990:82:457-64.

7. Kaye MP, Randall WC, Hageman GR, Geis WP, Pnola DV. Chronology and mode of retnnervation of the surgically denervated canine heart: functronal and chemical correlates. Am J Physiol 1977;233:H431-H437.

\section{ORAL ANTICOAGULANT DRUGS}

To the Editor: In his article on oral anticoagulant drugs (June 27 issue), Hirsh gives an excellent review of this important subject. We disagree, however, with his interpretation of the literature on oral anticoagulant treatment in patients with tissue heart valves and patients with mechanical-valve prostheses.

With regard to patients with tissue heart valves, the study by Turpie et al. ${ }^{2}$ compared two levels of intensity of warfarin therapy. The authors concluded that the less intense regimen was as effective as the more intense regimen in preventing embolism. However, the yearly incidence of major embolisms and minor embolisms as defined by the authors was 8 percent and 44 percent, respectively. Even though there was no difference between the two levels of anticoagulation, the incidence of thromboembolism was unacceptably high in both groups of patients. Although these results led Turpic et al. - and Hirsh ${ }^{\prime}$ to conclude that the less intense regimen was no less eflective, in our view one may conclude only that both regimens were equally ineffective.

With regard to patients with mechanical prosthetic valves, the study by Saour et al., ${ }^{3}$ in which a regimen with very high intensity was compared with one with a lower intensity, revealed no difference between the two treatment groups in the incidence of thromboembolism. A different picture emerges when the level of anticoagulation achieved, rather than the level targeted, is taken into account: all thromboembolic events occurred when the level was below the lower limit of the target zone of the high-intensity regimen. In other words, the high-intensity regimen offered protection when the target was achieved. The same holds true for the bleeding episodes; 9 of the 13 major episodes occurred when the level of anticoagulation was above the upper limit of the high-intensity target zone. Since all thromboembolic events and most bleeding episodes occurred when the actual level of anticoagulation was outside the target zone, we conclude that patients with mechanical prosthetic valves who are given high-intensity anticoagulant drug treatment receive good protection against thromboembolism, with little risk, if the anticoagulant effect can be maintained within the target zone.

With regard to the recent study by Altman et al. ${ }^{4}$ in which two regimens of oral anticoagulant therapy were compared in patients with mechanical prosthetic valves, it should be noted that all these patients also received aspirin and dipyridamole. Thus, the results cannot be compared with those of oral anticoagulant therapy alone.

F.J.M. V.D. MEER, M.D.

F.R. Rosendaal, M.D. S.C. Cannegieter, M.D.

E. BRIËT, M.D.

2300 RC Leiden, the Netherlands

University Hospital Leiden

1. Hirsh J. Oral anticoagulant drugs. N Engl J Med 1991:324:1865-75.

2. Turpie AGG, Gunstensen J, Hirsh J, Nelson H, Gent M. Randomised comparison of two intensities of oral anticoagulant therapy after tissue heart valve replacement. Lancet 1988:1:1242-5.

3. Saour JN, Steck JO, Mamo LAR, Gallus AS. Trial of different intensities of anticoagulation in patients with prosthetic heart valves. N Eng! J Med 1990; 322:428-32.

4. Altman R, Rouvier J, Gurfinke! E, et al. Comparison of two levels of anticoagulant therapy in patuents with substitute heart valves. J Thorac Cardiovase Surg 1991;101:427-31.

To the Editor: In his excellent review of oral anticoagulant therapy, Dr. Hirsh briefly discusses the development of methods for monitoring the prothrombin time during oral anticoagulant therapy and the present imprecision of such monitoring in this country that is due to the reluctance of physicians to use an International Normalized Ratio (INR) format for reporting results. To determine how widespread this reluctance is, we conducted a survey of laboratory supervisors at all 103 acute care hospitals in Massachusetts in the winter of 1990-1991.

Supervisors at 86 percent of the hospitals responded. They were using nine different preparations of thromboplastin (56 individual lots) from six companies and 16 different instruments to monitor prothrombin time. The International Sensitivity Index (ISI) of these 56 lots of thromboplastin ranged from 1.89 to 2.74 . Ninetynine percent of the labaratories reported results in seconds; only 4 percent also reported results in terms of the INR. Two thirds of respondents indicated they had only a vague understanding or none of the importance of an ISI or the INR.

This brief survey clearly indicates the widespread failure on the part of these hospitals to report the results of prothrombin-time measurements in a meaningful and easily comparable fashion. The wide variation in the sensitivity of thromboplastins as indicated by the ISI values could result in widely divergent levels of anticoagulation, even if all centers used the recommended therapeutic range* for most indications - 1.3 to 1.5 times the control value. Intensive educational efforts are needed to change practices in monitoring oral anticoagulant therapy, at least in Massachusetts.

Jack E. ANSEll, M.D.

Worcester, MA 01655 University of Massachusetts Medical School

*Hirsh J, Deykin D, Poller L. "Therapeutic range" for oral anticoagulant therapy. Chest 1986;89:Suppl:11S-15S

\section{Dr. Hirsh replies:}

To the Editor: v.d. Meer et al. question my interpretation of three studies that compared two levels of oral anticoagulant therapy in patients with prosthetic heart valves. Specifically, they suggest that the high-intensity regimen is safe if the prothrombin time is maintained in the target zone. This conclusion does not negate the observation that in all three studies the less intense regimen was as effective as the more intense regimen and resulted in less bleeding. 
The patients with tissue prosthetic heart valves received treatment for three months to cover the high-risk period (this is standard practice). The primary measure of outcome, established a priori, was the incidence of major embolism over a three-month period 2 percent in both groups. Extrapolating this figure to an annual incidence of 8 percent is inapproprate since the risk of embolism in these patients is limited largely to the initial three months after operation. A minor embolism was defined as any reversible cerebral event, and in many instances an event may not have been embolic in nature. The risk of bleeding (including major bleeding) was signifcantly higher in the group given the high-intensitv regimen. On the basis of these findings (and in the absence of contrary findings), it would be difficult to justify the use of high-intensity anticoagulant therapv in patients with tissue prosthetic heart valves.

The point at issue in the study by Saour et al. was not whether high-intensity therapy might have produced less bleeding if the target range had not been exceeded, but whether the less intense treatment appeared to be as effective and safer. The study by Altman et al. merely confirmed the principle that the use of a more intense regimen in patients with mechanical prosthetic valves produces more bleeding without obvous improvement in efficacy.

The results of these and other clinical trials to determine the optimal therapeutic range have challenged our clinical prcjudices. The onus is now on the proponents of more intense therapy to demonstrate the superiority of therr favored approach.

The survey described by Dr. Ansell emphasizes the sorry state of the reporting of prothrombin times by participating hospitals in Massachusctts. Surely, this is an issue that should be addressed by appropnate medical societies, regulatory agencıes, and hospital quality-assurance programs.

JaCk Hirsh, M.D.

Hamilon, ON L8V 1C3, Canada Hamilton Civic Hospitals Research Centre

\section{PRESENCE OF THE FRENCH CANADIAN DELETION IN A FRENCH PATIENT WITH FAMILIAL HYPERCHOLESTEROLEMIA}

To the Edtor: Familial hypercholestcrolemia is an autosomal dominant disorder due to mutations in the low-density-lipoprotein (LDL)-receptor gene. In the French Canadian population, 60 percent of patients with familial hypercholesterolema have the same large deletion in the $5^{\prime}$ region of the LDL-receptor gene (the French Canadian deletion), ${ }^{1}$ whereas in most other populations each unrelated patient with familial hypercholesterolemia seems to have a different LDL-receptor mutation. ${ }^{2}$ The high frequency of the former deletion makes it a useful tool for early diagnosis of familial hypercholesterolemia in French Canadians. The question arises, however, whether this mutation is frequent in France, since French Canadians are descended from French settlers

To answer this question, we studied 72 unrelated patients with familial hypercholesterolemia, 30 from the Paris area and 42 from the western part of France (the place of origin of many French Canadians). Ten micrograms of leukocyte DNA from each patient was digested with the restriction enzymes ${ }^{1} \mathrm{X} b a \mathrm{I}$ and $\mathrm{KpnI}$ or $\mathrm{XmnI} \mathrm{I}^{3}$ The digested DNA was fractionated on 0.7 percent agarose gels and transferred to nylon membranes. The membranes were hybridızed with a radiolabeled probe and subjected to autoradiography. The probe was the exon 2 of the LDL-receptor gene, obtained by polymerase-chain-reaction amplification from the full-length LDL-receptor complementary DNA. The autoradiograms of all patients revealed one fragment of $9 \mathrm{~kb}$ after digestion with $X b a \mathrm{I}$ and $K p n I$ or one fragment of $12 \mathrm{~kb}$ after digestion with $\mathrm{XbaI}$ and $X \mathrm{mnI}$. One patient. from the western part of France, had a second fragment, of $19 \mathrm{~kb}$, after digestion with $X b a \mathrm{I}$ and $X m n I$; this fragment resembled that found in the French Canadians, ${ }^{3}$ thus revealing the presence of the French Canadian deletion.

This finding supports the French origin of the French Canadian deletion. However, it suggests that the high frequency of this muta- tion among French Canadian patuents with hypercholesterolemia is due to a founder effect rather than a high frequency in the population of origin.

75018 Paris, France

F. Fumeron, Ph.D. B. Grandchamp, M.D., Ph.D. J. Fricker, M.D., Ph.D. Faculté Xavier Bichat

44035 Nantes, France

M. KREMPF, M.D Centre Hospitalier Régjonal Universitaire de Nantes

76233 Boisguillaume, France

L.-M WOLF, M.D. Centre Hospıtalier Régıonal Unversitaire de Rouen

M -C. Khayat, Ph.D.

14033 Caen, France Centre Hospitalier Régional Universitare de Caen

O. BOIFFARD, M.D

86021 Poitiers, France

Centre Hospitalıer Régional Unversitaire de Poutuers

75018 Paris, France

M. Apfelbaum, M.D

Faculté Xavier Bichat

I Hobbs HH, Brown MS, Russell DW, Davignon J, Goldstein JL. Deletion in the gene for the low-density-lipoprotem receptor in a mapority of French $\mathrm{Ca}_{\mathrm{a}}$ nadians with familial hypercholesterolemia N Engl J Med 1987,317.734-7

2. Hobbs HH, Russell DW, Brown MS, Goldstein JL The LDL receptor locus in familal hypercholesterolemia: mutational dnalysis of a membrane protein Annu Rev Genet 1990.24.133-70.

3. Ma YH, Betard C. Roy M. Davignon J, Kessing AM Identification of a second "French Canadran" LDL receptor gene deletion and development of a rapid method to detect both deletions. Clin Genet 1989.36.219-28

\section{INTRAUTERINE GROWTH RETARIDATION. PERINATAL DEATH, AND MATERNAL. HOMOCYSTEINE LEVELS}

To the Editor: Intrauterne growth retardation is associated with atheroma-like lesions in the arteries of the placental bed.' The finding of increased resistance to uterine-artery blood flow is predictive of both preeclampsia and intrauterine growth retardation. ${ }^{2}$ Hyperhomocysteinema has been identified as an important risk factor for occlusive vascular disease in nonpregnant adults, ${ }^{3}$ but its effect on the uteroplacental vasculature is not known $W_{\text {omen }}$ with homocystinuria due to cystathonine $\beta$-synthase deficiency may have an increased incidence of pregnancy loss, ${ }^{4}$ and a recent report by Steegers-Theunissen et al. (April 25 issue)' suggests that mothers of babies with neural-tube defects have increased curculating homocysteme concentrations.

We examined the obstetrical histories of eight women who were obligate heterozygotes for homocystınuria. These women had had a total of 34 pregnancies between 1960 and 1990,4 (12 percent) ending in spontaneous abortion. The mean $( \pm S D)$ birth weight for the remaining 30 babies was $3408 \pm 774 \mathrm{~g}$, which was not significantly different from the value for the general population. Each woman had one infant with homocystinuria; the mean birth weight of these eight infants was $3652 \pm 574 \mathrm{~g}$. Among the 30 infants, there were three perinatal deaths, yselding a high perinatal mortalsty rate of 100 per 1000 . One, who weighed about $750 \mathrm{~g}$, was stillborn. A second infant with a neural-tube defect (spina bifida) died two weeks after delivery. The third was an infant delivered at 31 weeks' gestation, because of severe preeclampsia, to a mother who had had a previous uncomplicated pregnancy. The baby weighed $1220 \mathrm{~g}$ and died from complications of prematurity. In none of these three infants was a homocystinuric disease confirmed or excluded.

We also measured fasting plasma total homocysteine concentrations in mothers who delivered babies with growth retardation at the Coombe Lying-In Hospital. Women whose period of gestation 